\title{
RELATIONSHIP BETWEEN SOCIAL SKILL AND LEARNING OUTCOMES OF BIOLOGY STUDENT ON BASIC CHEMISTRY COURSE
}

\author{
Syarifa Wahidah Al idrus ${ }^{1 *}$ and Jono Irawan ${ }^{2}$ \\ ${ }^{1}$ Chemistry Education Department, FKIP University of Mataram, Mataram, Indonesia. \\ ${ }^{2}$ Magister of Science Education, University of Mataram, Mataram, Indonesia. \\ *Email: syarifaidrus@unram.ac.id
}

Acceped: October, 23 2021. Approved: November, 03 2021. Published: November, 172021

\begin{abstract}
This study aims at determining the level of students' social skills and the relationship between the social skills and learning outcomes of the basic chemistry student course in the first semester of the Biology Education Department, Faculty of Teacher Training and Education, University of Mataram. The sample of this study was saturated consisted of 49 students. This study is descriptive quantitative research with quantitative correlational design, and data collection techniques were conducted by giving research instruments in the form of questionnaires. The results showed that the first-semester student had social skills mainly in the moderate category $(59.18 \%)$. There was a positive and significant relationship between social skills and students' learning outcomes. The value of the coefficient of determination of X2 against $\mathrm{Y}(\mathrm{r} 2 \mathrm{x} 2 \mathrm{y})$ is 0.400 . It shows that the social skill variable contributes to chemistry learning achievement by $40 \%$, while other variables determine $60 \%$.
\end{abstract}

Keywords: social skills, learning outcomes.

\section{INTRODUCTION}

Indonesian law number 20 of 2003 explains that the national education system aims to develop capabilities and form dignified national character and civilization to educate the nation's life [1]. Education will lead to self-motivation to be better in all aspects of life. Educational philosophy is the process of acquiring learning experiences so that students can develop their potential and solve problems in everyday life [2]. The nature of education is if students can achieve a high quality of life [3]. Education is an indicator of a country's progress, in Indonesia, especially, starting from preschool to university level.

Higher education is an educational institution where all learning processes are conducted. In addition, it also develops the personality and potential of students to grow and develop by the goals of national education. The learning process in higher education can change the students' behavior the interactions with their environment. Expected behavioral changes include changes in knowledge, skills, and attitudes. Learning outcomes are successful if there is a longlasting change that is applied in everyday life. Some researchers report that the learning process tends to be theoretical, so it cannot solve real environmental problems. Thus, students are less skilled at solving problems in everyday life [4].

The nature of the material delivery, which is theoretical, also causes students to consider all science material as difficult, such as Chemistry. Chemistry is deemed to be complicated by students because of the theoretical learning process. Chemistry, which is naturally abstract, and taught without being associated with everyday life, will not be meaningful for students. Thus, Chemistry is less desirable compared to the other sciences. Learning models that do not lead to daily life and are far from providing life skills make the material less interested [6]. Less interesting material will be more meaningful if delivered contextually.

Contextual learning not only conveys material theoretically but the learning experience and life skills are conveyed as much as possible. One of the life skills that must be trained is social skills. It is correlated with the explicit goals of education which is the realization of social goals among students. Family and school play the most significant role in transferring social attitudes and social skills. Campus creates an atmosphere of socialization between individuals and teaches love, empathy, loyalty, and cooperation. The most important one is that social skills are needed to achieve various social, emotional, and individual goals [3].

Social skills arise from interaction with the environment based on norms and are used to deal with problems in everyday life. [7]. Someone's social skills can be observed when solving problems in groups and repeatedly interacting with each other regardless of group conditions. The low and high social skills of a person are determined from the characteristics of the social skills that appear, such as having social awareness, skills in conveying ideas, ability to communicate with other people or groups, high empathy, and capability of interacting.

The observations during the lecture process show that students with good social skills can complete assignments well and quickly. One of the reasons for the accuracy in completing assignments is the communication skills of students in groups. Students with weak social skills will have difficulty interacting in groups. They will walk alone in solving problems, with a resolution process that is not optimal. Results that are not optimal will have an 
impact on the evaluation of learning outcomes. Active students will get a better experience so that they will get maximum learning outcomes. Students' social attitudes (social skills) have a significant effect on learning outcomes [8]. Student learning outcomes with good social skills will tend to be good when the learning evaluation is conducted. In addition, one of the determinants of a person's success is social skills. Social skills will affect academic achievement. Academic success is also determined by the student's social skills competence [9]. Social skills competence can develop students' intellectuals because it is influenced by interpersonal relationships with teachers [10] and their peers.

Basic Chemistry is a compulsory subject that first-semester students in the science major must take. Semester 1 is a period of transition from high school to college. This condition will require a reasonably high adjustment for students, such as the lecture process, lecturers, and new friends. The adjustment process will run well if communication is well. The social skills of a student strongly influence one's ability to communicate well.

Because of the importance of social skills in the learning process, it is necessary to identify students' social skills competencies during lectures to optimize the learning outcomes and find the relationship between social skills and learning outcomes for Basic Chemistry courses.

\section{RESEARCH METHODS}

The population and sample in this study were students of the Basic Chemistry Course, Department of Biology Education, 2019/2020. The sampling technique used is saturated sampling with a total of 49.

Social skills data was obtained using a questionnaire with four alternative answers. Data on learning outcomes obtained from the value of the Basic Chemistry Course. Analysis of social skills questionnaire data uses a Likert scale to measure attitudes, opinions, and perceptions of a person or group of people about social phenomena [11]. In the Likert scale, qualitative data is transferred into quantitative data.

Table 1. Alternative Answers Scores

\begin{tabular}{lcc}
\hline \multicolumn{1}{c}{ Alternative } & $\begin{array}{c}\text { Weigh } \\
\text { Answers }\end{array}$ & $\begin{array}{c}\text { Scores } \\
\text { Positive }\end{array}$ \\
Negative \\
\hline Always & 4 & 1 \\
Often & 3 & 2 \\
Seldom & 2 & 3 \\
Never & 1 & 4 \\
\hline
\end{tabular}

The formula used is:

social skills $=\mathrm{A} / \mathrm{B} \times 100$

Note:

$\mathrm{A}=$ sum of total score obtained

$\mathrm{B}=$ maximum sum
The social skill value obtained from the calculation is then searched for the average value and standard deviation based on the social skill category using the guidelines as shown in Table 2 .

Table 2. Criteria for Percentage of Social Skills

\begin{tabular}{ll}
\hline Category limit & Category \\
\hline $\mathrm{x}<(\mu-1,0 \sigma)$ & Low \\
$(\mu-1,0 \sigma) \leq \mathrm{x}<(\mu+1,0 \sigma)$ & Medium \\
$(\mu+1,0 \sigma) \leq \mathrm{x}$ & Hight \\
\hline
\end{tabular}

The results of the social skills obtained by the category are then presented using the formula: $P={ }^{\mathrm{f} / \mathrm{N}} \times 100 \%$ [12]

Note:

$\mathrm{P}=$ Percentage

$\mathrm{f}=$ frequency at the percentage being searched $\mathrm{N}=$ Numbers of Frequencies

Analysis of learning outcomes uses correlation and regression to see the relationship between social skills and learning outcomes. The effect of social skills on learning outcomes is expressed in the regression line equation $\mathrm{Y}=\mathrm{a}+\mathrm{b} 1$ $\mathrm{X}$. Further tests are conducted. The next stage is the calculation of the correlation coefficient and the significance test. All processes of data analysis use the SPSS program.

\section{RESULTS AND DISCUSSION Students' Social Skills Level}

Social skills can be defined as special abilities related to interpersonal intelligence. Social skills can be observed when a person can conduct a reciprocal process with individuals or groups in a problem-solving process [13]. Semester 1 students would experience changes in social skills from the high school level. With social changes, people have to acquire more social skills through official programs, and the lack of social skills can put teenagers in high-risk situations [14]. Social skills are influenced by culture and social groups, and social skills in social relations and behavior are very important [15]. Thus, social skills play a very important role in student interaction on campus.

Campus life is expected to train students' social skills more as they must be able to communicate with friends to be able to do many tasks commonly done in groups. They must also be able to communicate with lecturers and administrative staff in the campus environment. Thus, this three-way communication will significantly help students to complete their studies well. The analysis results on the level of social skills possessed by the first-semester biology education students are depicted in Figure 1. 


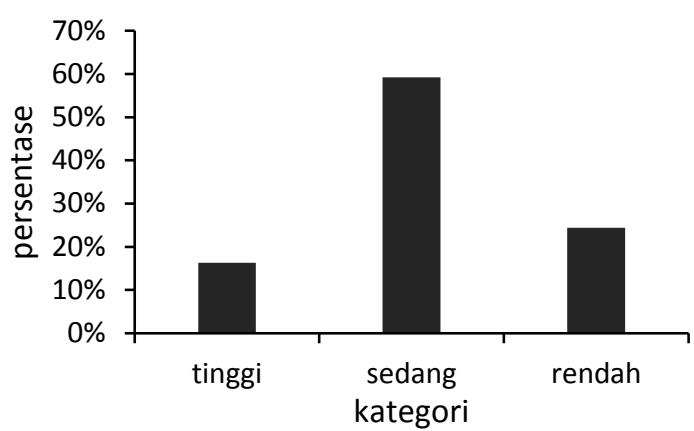

Figure 1. Social Skill Percentage

The graph shows that most of the students' social skills are in the medium category, followed by the low category and a small portion in the high category. This indicates that the social skills that exist in students are still not optimal. For example, many students are still less communicative and active when discussing with group friends. It can be caused by the condition of the first semester students who are still in the transition period from high school so that the learning process that can train students' social skills is very important. Things that can be done include: being a good listener when the teacher explains the learning material, communicating intensely with both lecturers and other students to get more information, especially in learning, and having the courage to express opinions, especially during group discussions. In addition, collaboration in groups is also needed to improve students' social skills. Giving a variety of learning models that prioritize working in groups and solving problems is something that needs to be given. Cooperative, project-based, and discovery learning models are models that can train students' social skills.

The cooperative model provides opportunities for students to develop interpersonal, social, and teamwork competencies that can determine their professional and social success [16]. In the learning steps of the cooperative model, students imitate other friends (modeling), practice learned communicative and social skills, and receive immediate information about their behavior from their friends (feedback). There is a transfer of knowledge to other different situations (generalization) [17]. Thus, the process of social skills training can be conducted in the cooperative learning model.

Social skills in learning will emerge when working with other people in study groups. In addition, social skills can also be observed in asking questions, expressing opinions, and appreciating members' views inside and outside the group. Mutual respect in the learning process can train students' communication, ways of thinking, and acting. Good communication between friends and lecturers can increase cooperation and expand the information in the implementation of learning. Good communication between lecturers and between students will improve learning outcomes. Communication, in this case, is a relationship of giving and receiving and understanding. Good communication will produce a good performance.

\section{Relationship of Social Skills with Chemistry Learning Achievement}

A single regression equation is obtained from simple regression analysis between social skills and chemistry learning achievement: $\mathrm{Y}=$ $43.29+1.064 \mathrm{X}$.

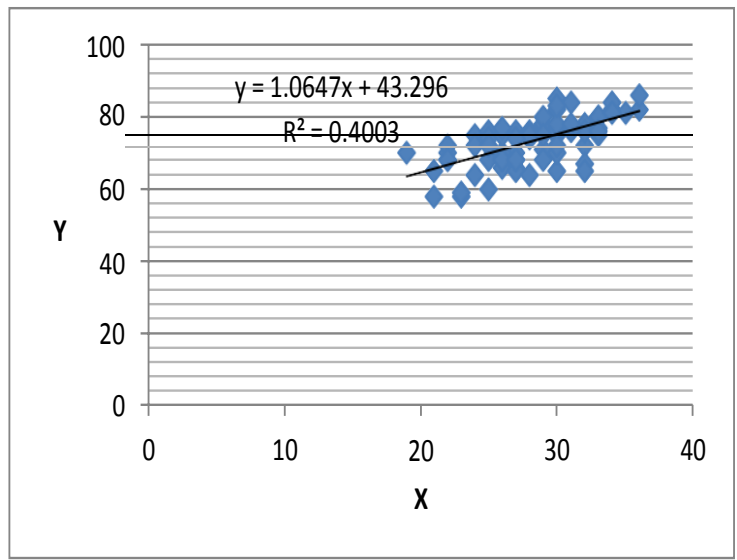

Figure 2. Graph of Correlation between Social Skills and Chemistry Learning Achievement

From this linear regression equation, it is known that when the value of social skills (X2) is positive or the value of social skills increases, the learning achievements also increase. If the social skills increases, learning achievement will increase. On the other hand, if social skills are low, learning achievement will decrease. The relationship between social skills and Basic Chemistry learning achievement is unidirectional. The value of the coefficient of determination of X2 against $\mathrm{Y}(\mathrm{r} 2 \mathrm{x} 2 \mathrm{y})$ is 0.400 . It shows that the social skills variable contributes to the learning achievement of Chemistry by $40 \%$, while $60 \%$ is determined by other variables that are not examined. Social skills are a factor that determines academic success and can predict individual developmental achievement [9]. Moreover, social skills determine academic success and competencies that are valued by employers [18].

Students must possess social skills so that the learning process runs in two directions and can work together in study groups. Social skills will increase students' abilities to ask questions, express opinions, and respect others. Students are also required to develop their ability to communicate, think, feel, and act to create good relationships between students. In addition, with communication, an increase in cooperative relationships between students in learning occurs. Good communication causes more information obtained from fellow students or lecturers as input, especially in the learning process. The meaningful learning process 
will emerge with positive inputs. Meaningful learning will provide good learning outcomes. Good learning outcomes will be formed if communication is well established between students and lecturers and between students [19].

\section{CONCLUSION}

The social skills of the 2019/2020 Biology students are mainly in the medium category $(59.18 \%)$. Social skills affect learning achievements, whereby increasing one's social skills positively affects learning achievement. Social skills can help students improve their understanding of themselves, especially in terms of social skills. Thus it helps them optimize their learning outcomes. It is recommended that educators train and maintain student social skills, which are helpful in improving the quality of learning.

\section{REFERENCES}

[1] Hindarto, Nur Khoiri, N \& Sulhadi. 2011. Pengembangan Perangkat Pembelajaran Fisika Berbasis Life Skill Untuk Meningkatkan Minat Kewirausahaan Siswa. Jurnal Pendidikan Fisika Indonesia. 7(2): 84.

[2] Amijaya, L. S., Ramdani, A., \& Merta, I. W. (2018). Pengaruh model pembelajaran inkuiri terbimbing terhadap hasil belajar dan kemampuan berpikir kritis peserta didik. Jurnal Pijar Mipa, 13(2), 94-99.

[3] Mujakir. 2012. Pengembangan LIfe Skill dalam Pembelajaran Sains. Jurnal Ilmiah DIDAKTIKA. 13(1): 1.

[4] Sapitri, R. D., Hadisaputra, S., \& Junaidi, E. (2020). Pengaruh penerapan praktikum berbasis kearifan lokal terhadap keterampilan literasi sains dan hasil belajar. Jurnal Pijar Mipa, 15(2), 122-129.

[5] Bahriah, E. S., Agung, S., \& Yudiantono. 2016. Analisis Life Skills Siswa Pada Apek Spesific Life Skills Dalam Pembelajaran Koloid Berbasis Proyek. Prosiding Seminar Pendidikan IPA Pascasarjana UM. 1: 1120.

[6] Rice LM, Wall CA, Fogel A, Shic F. 2015. Computer-assisted face processing instruction improves emotion. Journal of Autism and Developmental Disorders. Vol: 45, 2176-2186

[7] Thalib, Syamsul B. 2010. Psikologi Pendidikan Berbasis Analisis Empiris Aplikatif. Jakarta: Kencana

[8] Naijan. 2014. Pengaruh Metode Pembelajaran dan Sikap Sosial Terhadap Hasil Belajar Sejarah Siswa SMAN 12 Tangerang Selatan. Journal Pendidikan Sejarah Vol: 3 No:1:2014

[9] Caprara, G. V., Barbaranelli, C., Pastorelli, C., Bandura, A., \& Zimbardo, P. G. 2000. Prosocial foundations of children's academic achievement. Psychological Science, 11, 302306.
[10] DiLalla, L. F., Marcus, J. L., \& Wright-Phillips, M. V. 2004. Longitudinal effects of pre-school behavioral styles on early adolescent school performance. Journal of School Psychology, 42, 385-401.

[11] Sugiyono. 2015. Metode Penelitian Dan Pengembangan. Bandung: Alfabeta.

[12] Siregar, S. 2012. Statistik Parametrik untuk Penelitian Kuantitatif. Jakarta: PT. Bumi Aksara

[13] Ahmadi, Abu. 2004. Sosiologi Pendidikan. Jakarta: Rineka Cipta.

[14] Wang H, Lin C. 2015.Factor analysis of a social skills scale for high school students. Psychol Rep. Vol. 117.566-79

[15] Das P, Basu M, Dhar G, Mallik S, Pal R. 2015. Nutritional status and morbidity pattern of government primary school children in north Kolkata of West Bengal, India. South East Asia J Public Health .Vol.2.13-7.

[16] Santiago, M.L., Benito, L.B., Elena, F.C., Maria, I. P. R., dan Damian, I.G., 2018. Cooperative Team Learning and the Development of Social Skills in Higher Education: The Variables Involved. Front. Psychol. https://doi.org/10.3389/fpsyg.2018.01536

[17] León, B. 2006. Elementos mediadores en la eficacia del aprendizaje cooperativo: entrenamiento previo en habilidades sociales y dinámica de grupos. An. Psicol. 22, 105-112.

[18] OECD. (2015). PISA 2015 Assessment and Analytical Framework: Science, Reading, Mathematic, Financial Literacy and Collaborative Problem Solving. Paris: OCDE, doi: 10.1787/9789264281820-8-en

[19] Ode, W., Saefuddin, \& Tewa, Y. 2019. Analisis Aspek-Aspek Life Skills Yang Muncul Pada Pembelajaran Kimia Pokok Bahasan AsamBasa Siswa Kelas XI IPA SMAN 1 Batauga. Jurnal Pendidikan Kimia Universitas Halu Oleo. 4(1): 65-71. 